\title{
THE ERADICATION OF CORRUPTION AND THE ENFORCEMENT OF THE LAW IN INDONESIA AS SEEN THROUGH THE LENS OF LEGAL PHILOSOPHY
}

\author{
Dany Tri Hutama Hutabarat ${ }^{1}$, Egi Delardi ${ }^{2}$, Ade Irwansyah $^{3}$, Donni Bascara ${ }^{4}$, Bayu Ansori ${ }^{5}$, \\ Faisal Tanjung ${ }^{6}$, Samdoni Jarwal Sinaga ${ }^{7}$, Muhammad Tuah ${ }^{8}$, Rizki Adrian ${ }^{9}$, Agus Budi ${ }^{10}$, \\ Annisya Raya Tanjung ${ }^{11}$, Nurcahaya ${ }^{12}$, Dinda Ayu Mahvira ${ }^{13}$, \\ Vivi Melvita Sari ${ }^{14}$, Ahmad Helmisyam Silitonga ${ }^{15}$

\begin{abstract}
Corruption is a product of the attitude of life of a group of people who use money as a standard of truth and as absolute power. Corruption has been going on for a long time, since the times of Ancient Egypt, Babylonia, Rome until the Middle Ages and until now. The purpose of this study is to determine the eradication of corruption and law enforcement in terms of the perspective of legal philosophy as a philosophy of implementing positive law in Indonesia. This study is normative legal research with descriptive method which explains that this legal research is carried out using primary legal materials, secondary legal materials and tertiary legal materials. Philosophy of Law which is the basic foundation of thinking in the application of any applicable legal rules and is considered in many branches of science gets special attention on the enforcement of corruption which should be done in eradicating corruption so that enforcement is not only based on written rules alone in eradicating but the eradication of corruption animates law enforcement in enforcement of corruption, written laws can be regulated, but these rules can be implemented by the implementers so that when the rules apply at the time of a criminal act of corruption, they can be in line with what has been written in the laws and regulations.
\end{abstract}

Keywords: Corruption, Law Enforcement, Legal Philosophy

\section{INTRODUCTION}

Corruption is a product of the life attitude of a group of people who use money as a standard of truth and as absolute power. Corruption has been going on for a long time, from Ancient Egypt, Babylonia, Rome to the Middle Ages and until now. In essence, corruption is a "social parasite" that destroys the structure of government, and becomes the main obstacle to the running of government and development in general.

One of the most crucial issues to be solved by the Indonesian nation and government is the problem of corruption. This is because the longer the criminal act of corruption in Indonesia, the more difficult it is to overcome. The prevalence of corruption in Indonesia is alleged to have occurred in all development sectors and sectors. Moreover, after the implementation of regional autonomy, based on Law Number 22 of 1999 concerning Regional Government which was renewed by Law Number 32 of 2004, it was alleged that corruption occurred not only at the central level but also at the regional level and even penetrated to the lowest level of government. 
Although according to the decision of the Constitutional Court of the Republic of Indonesia, the existence of a Corruption Court which is regulated under Article 53 of Law no. 30 of 2003 is considered unconstitutional and provides an opportunity for lawmakers to form a Law on Courts for Criminal Acts of Corruption in particular, which is increasing, both in terms of quantity or amount of state financial losses as well as in terms of quality, which is increasingly systematic, sophisticated and in scope after it has expanded. in all aspects of society.

Corruption which is one of the Special Crimes as codified in all criminal acts regulated in the Criminal Code (KUHP) as the basis for Article 103 of the Criminal Code that everything regulated in Book I of the Criminal Code applies to the Special Criminal Law. According to Sudarto, the Special Criminal Law is defined as the provisions of the criminal law that regulate the specificity of the subject and his special actions. (bijzonderlijk faiten) (Siahaan, 2013).

The problem of corruption is a thing faced by humans that comes from the bad thoughts of humans themselves towards God where humans doubt or do not believe in God's provisions where good destiny and also the concept of fortune that has been arranged for him and his family by God Almighty has been arranged. Corruption is closely related to bad habits, cheating, falsifying and so on. Of course, corruption is a crime that is related between humans and other humans. It is impossible for corruption to stand alone (Bramantyo, 2020).

Corruption in all its forms is an extraordinary crime because it has the potential to lead to hypercrime. As explained by Baudrillard that crime becomes hyper when it transcends reality (common sense, law, culture, morality, etc.), until it develops in such a way as to reach a perfect level. However, corruption as a common enemy has not yet become part of the nation's moral movement. This reality is a big challenge for the realization of good governance in Indonesia (Haryati, 2015).

Another important problem faced by law enforcers in their efforts to eradicating corruption is precisely a commitment to cut the spread of corruption among law enforcement officials themselves, it can even be said that the weak authority of law enforcement in the field of eradicating corruption is more because the apparatus that should enforce the law does not consistently live up to the values that they want to uphold Ahmad Ali said that as long as the dirty broom hasn't been cleaned yet, so any talk of justice is bullshit (as long as the dirty broom is not cleaned, any talk justice wll be empty) (Ali, 2001).

Based on the description of the background above, the implementation of the corruption law still has not overcome the actions of the perpetrators and law enforcers in eradicating corruption so that the problem to be investigated is how corruption should apply based on legal philosophy and what smart steps should be taken in eradicating corruption. corruption.

\section{RESEARCH METHOD}

In researching the law which is a scientific activity, which is carried out in a systematic way and using certain thinking, has the aim of studying a special legal phenomenon in accordance with the events that are happening in the field, by looking for further analysis, after the analysis is carried out then examined in depth related to legal facts, and then solve a problem by drawing conclusions. To be able to find the truth that can be accounted for its authenticity, in conducting research using a method that is in accordance with the desired 
goal. In essence, a methodology must provide direction on the basis of studying first and then analyzing it in the environment at hand (Soekanto, 2008).

Based on the foregoing, the authors in this study used the following writing methods:

\subsection{Types of Research}

In conducting the research, the author uses a type of normative legal research method which explains that this legal research is carried out using studies from library materials or secondary data, further explained such as primary legal materials, secondary legal materials and tertiary legal materials. The materials are structured with measurable stages, only then reviewed so that conclusions can be drawn regarding the problem being studied (Soekanto, 2008).

\subsection{Nature of Research}

According to the field, this research is carried out in a descriptive manner, according to Soerjono Soekanto for descriptive research, namely: researching so that the data obtained are found as accurately as possible from the symptoms that are happening from human activities, as well as explaining the hypothesis, and confirming the old theory, in developing a new theory (Soekanto, 2008).

\subsection{Research Approach}

Normative legal research that is explained so that it can be structured systematically is carried out in a way so that the laws and regulations used are in accordance with the existing subject matter, so as to anticipate the confusion that is being studied, regarding the subject, object and obligations and rights to an existing legal event.

\subsection{Data Types and Data Sources}

One of the data used in conducting this research is based on secondary sources (secondary data), which means that the data are not obtained from the field directly, but are obtained from library materials which include reference books, legislation, original legal documents. reports obtained from the literature in accordance with the problem being researched (Soekanto, 2008). In this study, therefore the sources used are:

a. Primary Legal Material

b. Secondary Legal Material

Contains legal materials that explain the results obtained from primary legal materials on the results obtained in the explanation of scientific essays, groups of legal experts, and researched reports from print and mass media relating to the Eradication of Corruption and Law Enforcement in Indonesia from the perspective of legal philosophy

c. Tertiary Law Material

Material that will provide a clue and can clarify a research on primary and secondary law that is described is that it can provide an explanation of the meaning of words and references found in encyclopedias, legal dictionaries and others. 


\section{RESULT AND DISCUSSION}

\subsection{The Implementation of The Punishment for The Crime of Corruption Is Based on The Will of The Philosophy of Law as A Basis for Thinking}

Law arises from a sense of obligation embedded in the human soul, namely in the human mind and conscience, which behaves in a certain way towards and with respect to the existence of other humans, to create order and order in society in such a way that human dignity and nature are not oppressed (Suryatni, 2018).

Thought in the field of law begins with the study of philosophy which has been changing and is always evolving. The object of study is everything that is done thoroughly and systematically in understanding the law. The issue of justice has received great attention in the study of legal philosophy. According to Aristotle, justice is happiness related to human relations. The law that is formed must provide justice as its goal. Furthermore, Aristotle divides justice into general justice which provides equality for every human/individual and proportional justice based on their rights according to abilities, achievements and so on (Akmal \& Madda, 2021).

Punishment provides a definite expression and a genuine acknowledgment of the hatred that arises as a result of a crime, as well as the immorality that underlies it. So criminal law continues the principles that it is morally right to hate criminals, and criminal punishment affirms and justifies those feelings by giving to criminals, punishments that express them. for the violation of common conscience. Therefore, criminal law which is a means of social control and as a political product should be a sublimation of all societal values which are summarized and formulated by legislators and applied by the apparatus in the criminal justice system (Apriani, 2010).

In Article 2 of Law Number 31 of 1999 as amended by Law Number 20 of 2001 the definition of calm corruption has been stated in Article 2 and Article 3 states:

(1) Any person who unlawfully commits an act of enriching himself or another person in a corporation that can harm the State's finances or the State's economy shall be punished with life imprisonment or imprisonment for a minimum of 4 (four) years and a maximum of 20 (twenty) years. and with Rp. 200,000,000.00 (two hundred million) and a maximum of 1,000,000,000.00 (one billion).

(2) In the event that the criminal act of corruption as referred to in paragraph (1) is committed under certain circumstances, the death penalty may be imposed.

From the provisions of Article 2 of Law Number 31 of 1999 which has been amended by Law Number 20 of 2001, which mentions State Finance, what is meant by State Finance ?

Article 1 point 1 of Law Number 17 of 2003 concerning State finances states, "State finances are all rights and obligations of the State that can be valued in money, as well as everything both in the form of money and in the form of goods that can be used as State property related to the implementation of rights and the obligation." in the explanation of Law Number 17 of 2003 states, "weakness of legislation in the field of State finances is one of the causes of several forms of irregularities in the management of State finances. In an effort to eliminate these deviations and realize a sustainable fiscal management system in accordance with the basic rules set out in the Constitution and general principles that are 


\section{POLICY, LAW, NOTARY AND REGULATORY ISSUES (POLRI) \\ VOLUME 1 ISSUE 2 (2022)}

universally applicable in the administration of the State government, it is necessary to have a law that regulates the management of State finances" (Prijambodo, 2018).

\subsection{The Eradication of Corruption Strategies}

\subsubsection{How to Fight against Corruption in China}

The Chinese government does not indiscriminately fight corruption. last year it convicted about 621,000 people for corruption, including 51 at the ministry or provincial level. The fight to eradicate corruption has been a top priority during President Xi Jinping's administration. After the Chinese Communist Party achieved a remarkable victory against corruption, the president last month said that deep-rooted corruption still needed to be eradicated.

The party's Central Commission for Discipline Inspection on Sunday (13/1/2019) said that this year's action against corruption will be focused on several areas related to people's livelihoods and let people feel greater achievement, greater happiness and greater security. bigger.

They said the crackdown would also be aimed at preventing corrupt officials from interfering with a number of interests. In addition to tackling corruption directly, China will also seek to eliminate bureaucratic bias in the government and correct officials guilty of indifferent behavior while carrying out their duties, the government said.

China also wants to be more involved in the anti-corruption handling of the international community to hunt down suspects who have fled abroad. China managed to bring back 441 fugitives for corruption cases to the country from August to December last year.

\subsubsection{How to Fight against Corruption in Hong Kong}

The Hong Kong Corruption Eradication Commission or the Hong Kong Independent Commission Against Corruption (ICAC) is said to be the most successful institution in the world to eradicate corruption. Tony Kwok, Deputy Commissioner and Head of Operations for ICAC during 1996-2002, admitted that his institution was persistent in dealing with corruption.

ICAC was founded in 1974, when corruption in Hong Kong was massive. At that time, Tony said, Hong Kong could be the most corrupt city in the world. So massive, in Hong Kong there is a close relationship between law enforcement officers and organized crime syndicates. Call it gambling and drugs which at that time received protection from law enforcement elements.

When ICAC was formed, according to Tony, only a few were optimistic that this institution could bring about change. Most rate it as "Mission Impossible". However, within three years, we were successful in convicting 247 government officials, including 143 police officers. In the latest Millennium Survey, the establishment of ICAC ranks as the 6th most important event in Hong Kong's 150-year history. There are five steps ICAC in eradicating corruption as follows: (KAR, 2015)

1. ICAC is independent and directly responsible to the highest positions in Hong Kong. This, according to Tony, ensures that they are free to intervene when conducting an investigation. Thus, the agency can investigate people or institutions without suspicion and fear. 
2. ICAC has strong financial support. Annual budgets can reach US\$90 billion, about US\$15 per capita. Maybe only the ICAC, the corruption eradication commission, has the biggest budget in the world.

3. The ICAC has unusually broad powers to conduct investigations. ICAC is not only able to investigate corruption crimes committed in state and private institutions. However, it can also investigate all criminal acts related to corruption. ICAC has the authority to conduct bank account investigations, can ask witnesses to testify under oath, confiscate the suspect's property originating from a criminal act of corruption, to ban the suspect..

4. ICAC's professionalism was the first to conduct interviews of all the suspects documented in the video. He said, there were at least 120 people who worked with special training first.

5. The fifth factor is what he calls the "three-pointed fork". The three are investigation, prevention, and education. He reminded that education is an important key so that the public can participate in fighting corruption (Febari, 2015).

\subsubsection{Smart Solution: Progressive Law Enforcement Needed}

Starting from the view that the law is for humans, law enforcement should not only understand the positive law that applies, but how a law enforcer is able to raise values that lead to justice which is only based on a series of words or sentences in the legislation but on real justice.

Law enforcers must prioritize honesty, have empathy and concern for the suffering of the people due to corruption that has occurred so far. Legal interests must be the orientation and ultimate goal of law enforcement in dealing with corruption. Progressive law enforcement is no longer centered on regulations, but on the creativity of law enforcement to actualize the law in the right space and time. Progressive law enforcers can make creative interpretations of existing regulations, without having to wait for regulatory changes. Bad legal regulations do not have to be a barrier to justice for people who are victims of corruption, law enforcers can at any time interpret the regulations in dealing with certain cases.

Why is the focus of attention on law enforcement and not on regulations because the problem of law enforcement is basically a gap between normative law (das sollen) and sociological law (das sein) or the gap between proper community behavior and actual community behavior. Law enforcement against criminal acts of corruption that has been running so far is still focused on procedural justice which places great emphasis on aspects of regularity and the application of legal formalities only. In line with that, legal engineering has become a pretty strong scent in almost every law enforcement (Mahmud, 2021).

Therefore, the Indonesian government must immediately revise the law on eradicating corruption which must be adapted to the current developments, namely the industrial revolution 4.0. Because the Corruption Eradication Commission must have more authority to eradicate corruption, especially in terms of preventing corruption.

\section{CONCLUSION}

Philosophy of Law which is the basic foundation of thinking in the application of any applicable legal rules and is considered in many branches of science gets special attention on the enforcement of corruption which should be done in eradicating corruption so that enforcement is not only based on written rules alone in eradicating but the eradication of corruption animates law enforcement in enforcement of corruption, written laws can be 
regulated, but these rules can be implemented by the implementers so that when the rules apply at the time of a criminal act of corruption, they can be in line with what has been written in the laws and regulations.

Additionally, steps that should be implemented apart from laws and regulations that apply moral attitudes, love for the homeland, such as the idea of Pancasila and the 1945 Constitution, besides that it is also necessary to imitate law enforcement in countries that are able to handle law enforcement Corruption crime in the sense of being able to properly describe and interpret enforcement in Indonesia as smart steps so that efforts to deal with corruption in Indonesia can be completed and development in Indonesia can be consistent.

\section{REFERENCES}

Akmal, D. U., \& Madda, S. M. (2021). Memaknai Hukuman Mati Bagi Koruptor Berdasarkan Filsafat Hukum. Supremasi Hukum, 17(02), 40-47.

Ali, A. (2001). Keterpurukan Hukum di Indonesia: Penyebab dan Solusi. Ghalia Indonesia, Jakarta.

Apriani, L. R. (2010). Penerapan Filsafat Pemidanaan Dalam Tindak Pidana Korupsi. Jurnal Yudisial, 3(1), 1-14.

Bramantyo, R. Y. (2020). Perspektif Filsafat Hukum Terhadap Tindak Pidana Korupsi. Morality: Jurnal Ilmu Hukum, 6(1), 74-81.

Febari, R. (2015). Politik Pemberantasan Korupsi. Yayasan Pustaka Obor Indonesia.

Haryati, T. A. (2015). Korupsi Perspektif Filsafat Etika Aristoteles. STAIN Pekalongan Press.

KAR. (2015). Ini Lima Jurus KPK Hong Kong Sukses Berantas Korupsi Perlu diteladani oleh KPK RI. HukumOnline.Com. https://www.hukumonline.com/berita/a/ini-limajurus-kpk-hong-kong-sukses-berantas-korupsi-lt54db4fff7d 855

Mahmud, A. (2021). Pengembalian Aset Tindak Pidana Korupsi: Pendekatan Hukum Progresif. Bumi Aksara.

Prijambodo, H. S. W. (2018). Bunga Rampai Hukum dan Filsafat di Indonesia: Sebuah Catatan Pemikiran. Deepublish.

Siahaan, M. (2013). Korupsi: penyakit sosial yang mematikan. Elex Media Komputindo.

Soekanto, S. (2008). Pengantar Penelitian Hukum, Cet. 3, Jakarta: Penerbit Universitas Indonesia. UI Press.

Suryatni, L. (2018). Filsafat Pancasila Dan Filsafat Hukum Sebagai Dasar Rule Of Moral. Jurnal Ilmiah Hukum Dirgantara, 6(2). 